\title{
KNOWLEDGE AND PRACTICE OF STOMA CARE AMONG OSTOMATES AT B.P.KOIRALA MEMORIAL CANCER HOSPITAL
}

\author{
Radha Acharya Pandey, Sandhya Baral Govinda Dhungana
}

\begin{abstract}
Background: There are more than 1 million patients with a permanent colostomy and the number is increasing by the rate of 100000 per year. Clients with a new stoma must master multiple psychomotor skills to remove their pouch, clean the stoma and peristomal skin and empty and dispose of effluent from the pouch. Stoma care self-efficacy has been positively related to ostomy adjustment.
\end{abstract}

Objective: To assess knowledge and practice of stoma care among ostomates.

Method: This is a simple ddescriptive cross sectional study. A total of 94 ostomates who met eligible criteria were purposively sampled. Stoma self care efficacy scale and semi-structured questionnaire was used and face to face interview was done. Data were analyzed using SPSS version 16 program. T test was used to see the mean difference.

Result: The knowledge of ostomates on normal stoma and complication of stoma was adequate $(61.7 \%)$. Majority (92.6\%) respondents had good daily care practice like emptying pouch, hand washing before and after procedure and cleaning stoma. Majority of the ostomates suffered from physical problem $(89.4 \%)$. Of which maximum $72.3 \%$ had peristomal skin irritation, then came leakage and odour. More than half (64.9\%) of ostomates had higher efficacy.

Conclusion: On the basis of findings, it is concluded that there was significant difference in mean knowledge of ostomates with variables pre-operative teaching, training on stoma care, living with stoma for more than 12 months. There was significant difference in mean self care efficacy with variables duration of living with stoma and training on stoma care. Thus training on stoma care should be provided frequently to further improve self care efficacy.

Key words: knowledge, practice, ostomates, stoma care

\section{INTRODUCTION}

the increasing incidence of colorectal cancer and urinary cancer, stoma surgery rate is also increasing. Teaching on stoma care and stoma skills given by enterostomal therapist during post-operative and discharge period enable clients to increase self-efficacy in ostomy management. A variety of gastrointestinal/ genitourinary etiologies may necessitate the creation of a fecal or urinary diversion. These may include colostomy for colon-rectal cancer, diverticular disease, inflammatory bowel disease, intestinal obstruction, gastrointestinal trauma, and gynecological cancers [1]. Urostomy for Bladder Cancer and Congenital abnormalities and ileostomy 
for ulcerative colitis, crohn's disease, familial polyposis and complications of cancer [2].

According to hospital based cancer registry in Nepal 2007, Ca Urinary bladder is $6^{\text {th }}$ common in male $>64 \mathrm{yrs}$ whereas $\mathrm{Ca}$ rectum is $6^{\text {th }}$ common in female 15-34 yrs and male 1534 years [3]. According to medical record unit of B.P. Koirara Memorial Cancer Hospital (BPKMCH), Age and site wise distribution of Cancer patient, 2010, Ca urinary bladder $91, \mathrm{Ca}$ colon 59 , Ca rectum 69. Surgery performed in Urology Unit, radical cystectomy with illeal conduit 8 , low anterior resection of rectum 6 , loop colostomy 4 , hemicolectomy 7 [4].

Enterostomal Therapist Shanti Bajracharya first started stoma care in Nepal and opened a clinic in 1996. At the beginning, there were only seven ostomates [5]. According to data of 2010 from stoma clinics of Patan, Nepal Ostomy Association and B\&B, shows the total ostomy cases were 2085 of which colostomy 1000, Urostomy 400, Iliostomy 300 [6]. There are more than 1 million patients with a permanent colostomy in China, and the number is increasing by the rate of 100000 per year Clients with a new ostomy must master multiple psychomotor skills to remove their pouch, clean the ostomy and peristomal skin and empty and dispose of effluent from the pouch [7].

The adverse impacts on stoma patients are physical, psychological and social. The physical problems of ostomates included leakage, skin problems, ballooning and odor $[8,9]$. The most common physical problems with the stoma include leaking, peristomal skin problems, and the need for adaptation of stoma appliances and the need for adaptation of clothing to the presence and site of the stoma which has a significant impact on the patient's daily life [10].
It is generally understood that a stoma has a negative impact on people's quality of life. This negative impact can affect self-care practices that may result in inappropriate and costly use of supplies [11]. Stoma care selfefficacy is defined as the conviction by patients that they can successfully manage their stoma to minimize adverse outcomes. Stoma care self-efficacy has been positively related to ostomy adjustment [12].

While no research exists to define a minimum post-operative skill set for clients with a new ostomy, a consensus conference of Ostomy Care and Management Wound, Ostomy and Continence Nurses in the United States, 2007 concluded that the minimum post-operative skill set for persons with an ostomy should include: 1) ability to manipulate the pouch clip or spout if present, and 2) independently empty the pouch. Additional skills that need to be taught, whenever possible, included: 1) bathing, clothing and activity restrictions, 2) review of influence of prescription and overthe-counter medications on ostomy function, 3) influence of diet on ostomy function, 4) peristomal skin care, 5) odour control, 6) monitoring for complications, and 7) sexual counseling [13]. Any failure on the journey to achieving an effective return to normal life may make the treatment and its long term consequences, particularly the stoma, seem worse than the original illness [14].

\section{Methods}

Descriptive cross sectional research design was used in stoma clinic of B.P. Koirala Memorial Cancer Hospital (BPKMCH). Being a national level cancer care referral centre in Nepal, most of the colorectal cancer and urinary bladder cancer cases are treated with stoma surgery. Study population ostomates more than 19 yrs of age and performing self-care and who were attending stoma clinic during the time of data collection. A total of 94 respondents, who 
met eligible criteria were purposively sampled and interviewed face to face.

A structured and semi-structured interview schedule consisting of demographic characteristics, knowledge and practice related questions developed by reviewing literature. The content validity of the instrument was established seeking opinion of oncologist and related experts nurses and doctors. The instrument was then translated into Nepali language and opinion of language expert was obtained for comprehensibility and simplicity of language and for consistency of the content. The study was conducted after obtaining approval from the concerned authority. Anonymity, privacy and confidentiality were maintained during as well as after data collection.

All patients who met the criteria and who gave informed consent were interviewed. Review of the patient's medical record file was done to confirm the diagnosis of ostometes. The collected data were reviewed daily for completeness and accuracy. Edited data were entered into the Statistical Package for Social Science Software (SPSS) version 16.0 for statistical analysis using descriptive and inferential statistics.

\section{RESULTS}

Table 1: Socio-demographic information:

\begin{tabular}{lcc}
\multicolumn{3}{c}{$\mathrm{N}=94$} \\
Variables & Frequency & Percent \\
\hline Gender & & \\
Male & 58 & 61.7 \\
Female & 36 & 38.3 \\
\hline Age (years) & & \\
$20-29$ & & \\
$30-39$ & 10 & 10.6 \\
$40-49$ & 20 & 21.3 \\
$50-59$ & 15 & 16.0 \\
$60-69$ & 20 & 21.3 \\
70 years and above & 24 & 25.5 \\
& 5 & 5.3 \\
\hline
\end{tabular}

\begin{tabular}{|c|c|c|}
\hline Education level & & \\
\hline Illiterate & & \\
\hline Can read and write & & \\
\hline Primary(class 1-8) & & \\
\hline Lower secondary(class & 16 & 17.0 \\
\hline $9-10)$ & 22 & 23.4 \\
\hline Higher secondary(class & 25 & 26.6 \\
\hline $11-12)$ & 12 & 12.8 \\
\hline Higher education (above & 13 & 13.8 \\
\hline 12) & 6 & 6.4 \\
\hline Type of stoma & & \\
\hline Colostomy & & \\
\hline Ileostomy & 66 & 70.2 \\
\hline Urostomy & 8 & 8.5 \\
\hline & 20 & 21.3 \\
\hline $\begin{array}{l}\text { Duration of living with } \\
\text { stoma }\end{array}$ & & \\
\hline 口12 months & 44 & 46.8 \\
\hline$>12$ months & 50 & 53.2 \\
\hline $\begin{array}{l}\text { Duration of post- } \\
\text { operative } \\
\text { hospitalization }\end{array}$ & & \\
\hline 口 15 days & 36 & 38.3 \\
\hline$>15$ days & 58 & 61.7 \\
\hline Training on stoma care & & \\
\hline No & 66 & 70.2 \\
\hline Yes & 28 & 29.8 \\
\hline Pre-operative teaching & & \\
\hline No & 30 & 31.9 \\
\hline Yes & 64 & 68.1 \\
\hline
\end{tabular}

There were more males than females, comprising of $61.7 \%$ and $38.3 \%$ respectively. The age group 60-69 years which is the largest age group comprises $25.5 \%$. The mean age of the respondents was 48.9 years and range 21 to 80 years. Regarding the educational level of respondents $17 \%$ were illiterate, $23.4 \%$ could read and write, $26.6 \%$ primary education. Most of the ostomates $70.2 \%$ had colostomy, $21.3 \%$ had urostomy and rest $8.5 \%$ had ileostomy.

Majority, $61.7 \%$ had post-operative hospitalization of more than 15 days, $38.3 \%$ had post-operative hospitalization of less than or equal to 15 days. Maximum duration of post-operative hospitalization was 90 days, minimum was 6 days. Regarding duration of 
living with stoma, $53.2 \%$ of ostomates were living with stoma for more than 12 months and the rest $46.8 \%$ for less than or equal to 12 months. The mean duration of living with stoma was 26.41 months and standard deviation was 3.2419. Maximum duration of living with stoma was 216 months (18 years). Training on stoma care was received least $29.8 \%$ ostomates whereas majority $70.2 \%$ did not receive training on stoma. Pre-operative teaching on stoma was provided during stoma site marking and at OPD before consent by concerned doctor that include $68.1 \%$, remaining $31.9 \%$ did not receive preoperative teaching (Table 1).

Table 2: Ostomates Knowledge regarding Normal Stoma $N=94$

Knowledge on stoma Frequency Percent

\begin{tabular}{|c|c|c|}
\hline \multicolumn{3}{|l|}{$\begin{array}{l}\text { Color of normal } \\
\text { stoma }\end{array}$} \\
\hline Red & 64 & 68.1 \\
\hline Pale & 3 & 3.2 \\
\hline Black & - & - \\
\hline Don't know & 27 & 28.7 \\
\hline \multicolumn{3}{|l|}{$\begin{array}{l}\text { Appearance of } \\
\text { normal stoma }\end{array}$} \\
\hline Shiny and moist & 45 & 47.9 \\
\hline Has nodules & 1 & 1.1 \\
\hline Has cuts and torns & 1 & 1.1 \\
\hline Don’t know & 47 & 50.0 \\
\hline \multicolumn{3}{|l|}{$\begin{array}{l}\text { Normal peristomal } \\
\text { skin condition }\end{array}$} \\
\hline Similar to other skin & 61 & 64.9 \\
\hline Red & 2 & 2.1 \\
\hline Painful to touch & 4 & 4.3 \\
\hline Don’t know & 27 & 28.7 \\
\hline
\end{tabular}

Majority $68.1 \%$ ostomates have told that the color of normal stoma is red, $47.9 \%$ knew that normal stoma must be shiny and moist. Half $(50 \%)$ of the ostomates replied that they don't know the appearance of normal stoma. And $64.9 \%$ knew that the normal peristomal skin condition should be similar to normal skin of other body part (Table 2).
Table 3: Ostomates Knowledge regarding Complication of Stoma $\mathrm{N}=94$

Knowledge on Frequency Percent complication

\begin{tabular}{lcc}
\hline Black coloured stoma & & \\
is normal & & \\
No & 53 & 56.4 \\
Yes & 2 & 2.1 \\
Don't know & 39 & 41.5 \\
\hline
\end{tabular}

Stoma protruded $>2$

inch is normal

$\begin{array}{lll}\text { No } & 56 & 59.6\end{array}$

Yes $\quad 1 \quad 1.1$

Don't know $\quad 37 \quad 39.4$

Continued bleeding

from inside stoma for

$>10$ min is normal

$\begin{array}{lll}\text { No } & 76 & 80.9\end{array}$

Yes $\quad$ - $\quad$ -

Don't know $\quad 18 \quad 19.1$

The data illustrates that $56.4 \%$ ostomates knew it was not normal to have black coloured stoma, 59.6\% knew it was not normal to have stoma protruded $>2$ inch and $80.9 \%$ knew it was not normal to have continued bleeding from inside the stoma for $>10$ min (Table 3 ).

Table 4: Daily care practices $\mathbf{N}=94$

\begin{tabular}{lcc}
\hline Practices & Frequency & Percent \\
\hline Handwashing before & & \\
procedure & & \\
Yes & 79 & 84.0 \\
No & 15 & 16.0 \\
\hline Handwashing after & & \\
procedure & & \\
Yes & 94 & 100.0 \\
No & - & - \\
\hline
\end{tabular}




\begin{tabular}{lcc}
\hline $\begin{array}{l}\text { Practice of emptying } \\
\text { stoma pouch }\end{array}$ & & \\
Totally filled & 3 & 3.2 \\
Half filled & 45 & 47.9 \\
$1 / 3$ rd filled & 41 & 43.6 \\
$<1 / 3^{\text {rd }}$ & 4 & 4.3 \\
Others & 1 & 1.1 \\
\hline
\end{tabular}

\begin{tabular}{lll}
\hline $\begin{array}{l}\text { Technique of } \\
\text { cleaning stoma }\end{array}$ & & \\
$\begin{array}{l}\text { Periphery to centre } \\
\text { Centre to periphery }\end{array}$ & 71 & 75.5 \\
\hline
\end{tabular}

In the daily care practices of ostomates, $84 \%$ ostomates perform hand washing before cleaning stoma and changing stoma bag where as all of them perform hand washing after the procedure. Likewise $47.9 \%$ of ostomates empty the pouch when it is half filled, $43.6 \%$ of ostomates empty pouch whenever pouch is $1 / 3^{\text {rd }}$ filled, $4.3 \%$ empty it in $<1 / 3^{\text {rd }}$ filled. Remaining $1.1 \%$ empty the pouch whenever they feel it uncomfortable. $75.5 \%$ of ostomates clean stoma from periphery to centre and remaining clean from centre to periphery (Table 4).

Table 5: Practices regarding Physical Problem and management $\mathrm{N}=94$

\begin{tabular}{lcc}
\hline $\begin{array}{l}\text { Physical problems } \\
\text { and management }\end{array}$ & Frequency & Percent \\
\hline $\begin{array}{l}\text { Physical problem } \\
\text { related to stoma }\end{array}$ & & \\
Yes & 84 & 89.4 \\
No & 10 & 10.6 \\
\hline $\begin{array}{l}\text { Physical Problems } \\
\text { Leakage }\end{array}$ & 42 & 44.7 \\
$\begin{array}{l}\text { Peristomal skin } \\
\text { irritation }\end{array}$ & 68 & 72.3 \\
Odour & 18 & 19.1 \\
\hline
\end{tabular}

\section{Practice regarding} physical problem

Solving peristomal

skin irritation

Use of stoma powder

Attend stoma clinic

Clean stoma and

change pouch if

liquid seeps under

$$
52
$$

barrier

3

3.2

Others

Solving Leakage

Reducing size of

aperture of flange of

pouch

Use 2 piece pouch

Check adhesive pad

16

17

for proper seal

10

10.6

Others

\section{Solving odour}

Change diet

26

27.7

Increased fluid intake

Use deodrant

Others

(multiple response answer)

Physical problems due to stoma are unavoidable as majority $89.4 \%$ ostomates were having physical problem due to stoma formation. Among them 72.3\% had peristomal skin irritation, $44.7 \%$ had leakage and $19.1 \%$ had odour problem. Of the $72.3 \%$ having peri-stomal skin irritation, $55.3 \%$ use stoma powder, $3.2 \%$ attend stoma clinic, $22.3 \%$ clean stoma and change pouch if liquid seeps under barrier and remaining $4.3 \%$ in others consists of use of savlon, detol and cream to solve peri-stomal skin irritation. Of the $44.7 \%$ having stoma leakage, $27.7 \%$ clean stoma and check adhesive pad for proper seal, $17 \%$ clean stoma and reduce the size of the aperture of flange of pouch, $10.6 \%$ clean stoma and prefer use of 2 piece pouch to reduce leakage and remaining $4.3 \%$ in others include use of stoma belt, extra adhesive glue and tape. Of the $19.1 \%$ having odour 
problem, $10.6 \%$ change diet, $2.1 \%$ increase fluid intake, $3.2 \%$ use deodorant, $1.1 \%$ in
(Table 6). others do nothing to solve it (Table $5)$.

Table 6: Ostomates Self Care Efficacy N=94

\begin{tabular}{|c|c|c|c|c|c|c|}
\hline Items & $\begin{array}{c}1 \\
\text { Not } \\
\text { confident }\end{array}$ & $\begin{array}{l}\text { Slightly } \\
\text { confident }\end{array}$ & $\begin{array}{c}3 \\
\text { Fairly } \\
\text { confiden } \\
t\end{array}$ & $\begin{array}{c}4 \\
\text { Highly } \\
\text { confident }\end{array}$ & $\begin{array}{c}5 \\
\text { Extremely } \\
\text { confident }\end{array}$ & $\begin{array}{c}\text { Mean } \\
\text { Score } \\
\pm \\
\text { SD } \\
\end{array}$ \\
\hline $\begin{array}{l}\text { Apply the stoma collection } \\
\text { materials before leakages appear. }\end{array}$ & $34(36.2)$ & - & $7(7.4)$ & $42(44.7)$ & $\begin{array}{c}11 \\
(11.7)\end{array}$ & $2.95 \pm 1.54$ \\
\hline Prevent having leakages. & $34(36.2)$ & $2(2.1)$ & $11(11.7)$ & $38(40.4)$ & $9(9.6)$ & $2.85 \pm 1.50$ \\
\hline $\begin{array}{l}\text { Take care of the stoma in the right } \\
\text { way at home. }\end{array}$ & $7(7.4)$ & $26(27.7)$ & $4(4.3)$ & $47(50.0)$ & $10(10.6)$ & $3.28 \pm 1.19$ \\
\hline Prevent having skin problems. & $24(25.5)$ & $11(11.7)$ & $20(21.3)$ & $29(30.9)$ & $10(10.6)$ & $2.89 \pm 1.37$ \\
\hline $\begin{array}{l}\text { Prevent having stoma bleeding and } \\
\text { damage. }\end{array}$ & $35(37.2)$ & $4(4.3)$ & $28(29.8)$ & $18(19.1)$ & $9(9.6)$ & $2.59 \pm 1.40$ \\
\hline $\begin{array}{l}\text { Apply the stoma collection } \\
\text { materials in the way you learned to } \\
\text { do. }\end{array}$ & $33(35.1)$ & - & $4(4.3)$ & $47(50.0)$ & $10(10.6)$ & $3.01 \pm 1.53$ \\
\hline Prevent having obstruction. & $11(11.7)$ & $25(26.6)$ & $6(6.4)$ & $42(44.7)$ & $10(10.6)$ & $3.15 \pm 1.26$ \\
\hline $\begin{array}{l}\text { Follow the nurse's instructions for } \\
\text { handling the stoma. }\end{array}$ & $11(11.7)$ & $21(22.3)$ & $4(4.3)$ & $48(51.1)$ & $10(10.6)$ & $3.26 \pm 1.25$ \\
\hline $\begin{array}{l}\text { Follow the doctor's advice for } \\
\text { taking care of your stoma and } \\
\text { nutrition pattern. }\end{array}$ & - & $1(1.1)$ & $40(42.6)$ & $40(42.6)$ & $13(13.8)$ & $3.69 \pm 0.71$ \\
\hline $\begin{array}{l}\text { Take care of the stoma in the right } \\
\text { way outdoors. }\end{array}$ & $33(35.1)$ & $2(2.1)$ & $26(27.7)$ & $27(28.7)$ & $6(6.4)$ & $2.69 \pm 1.37$ \\
\hline $\begin{array}{l}\text { Take care of the stoma when you } \\
\text { are ill. }\end{array}$ & $33(35.1)$ & $10(10.6)$ & $26(27.7)$ & $20(21.3)$ & $5(5.3)$ & $2.51 \pm 1.30$ \\
\hline Wear most of the clothes you like. & $18(19.1)$ & $18(19.1)$ & $25(26.6)$ & $27(28.7)$ & $6(6.4)$ & $2.84 \pm 1.22$ \\
\hline $\begin{array}{l}\text { Carry out light duties in and around } \\
\text { the house (for instance washing up } \\
\text { and gardening). }\end{array}$ & $15(16)$ & $10(10.6)$ & $28(29.8)$ & $25(26.6)$ & $16(17.0)$ & $2.84 \pm 1.29$ \\
\hline
\end{tabular}

Values in ( ) represents percentage.

Self-care efficacy of ostomy management act as enablers as they struggle to re-establish a sense of normalcy following stoma surgery. Highest mean score was on statement "Follow the doctor's advice for taking care of stoma and nutrition pattern." Lowest mean score was on "Take care of stoma when you are ill." Mean self-care score $=38.94 \pm 1.55$. Minimum score 13 and maximum score 65

\begin{tabular}{lcccl}
\hline Knowledge & Score & N & \% & $\begin{array}{l}\text { Mean } \\
\pm \text { SD }\end{array}$ \\
\hline Adequate & $\mathbf{0 3 ( \mathbf { D }}$ & & & 3.77 \\
Knowledge & $50 \%)$ & 58 & 61.7 & \pm \\
Inadequate & $>3$ & & & 2.01 \\
Knowledge & $>50 \%)$ & 36 & 38.3 & \\
\hline
\end{tabular}

Table 7: Overall Knowledge Score: $N=94$

The data in table illustrates that more than half $(61.7 \%)$ respondents have adequate knowledge of normal stoma and 
complications. The mean knowledge score was $3.77 \pm 2.01$ (Table 7).

Table 8: Overall Daily Care Practice Score: $\mathbf{N}=94$

\begin{tabular}{|c|c|c|c|c|}
\hline $\begin{array}{l}\text { Daily } \\
\text { care } \\
\text { practic } \\
\text { e }\end{array}$ & Score & $\begin{array}{r}\text { Frequenc } \\
\mathrm{y}\end{array}$ & $\begin{array}{r}\text { Percen } \\
\mathrm{t}\end{array}$ & $\begin{array}{c}\text { Mea } \\
\mathrm{n} \pm \\
\mathrm{SD}\end{array}$ \\
\hline $\begin{array}{l}\text { Good } \\
\text { practice }\end{array}$ & $\begin{array}{l}\text { प } 2(\mathbf{\square} \\
50 \%) \\
>2\end{array}$ & 87 & 92.6 & $\begin{array}{l}3.55 \\
\pm 0.6 \\
3\end{array}$ \\
\hline $\begin{array}{l}\text { Poor } \\
\text { practice }\end{array}$ & 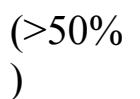 & 7 & 7.4 & \\
\hline
\end{tabular}

Majority (92.6\%) had good practice regarding daily care practices like hand washing before and after procedure, pattern of emptying the pouch and cleaning the stoma from periphery to centre. The mean score was $3.55 \pm 0.63$ (Table 8).
Table 9: Overall Self Care Efficacy Score

\begin{tabular}{lllll}
\multicolumn{5}{c}{$\mathbf{N}=94$} \\
$\begin{array}{l}\text { Self } \\
\text { care } \\
\text { efficac }\end{array}$ & Score & $\begin{array}{l}\text { Frequenc } \\
\text { y }\end{array}$ & $\begin{array}{l}\text { Percen } \\
\mathrm{t}\end{array}$ & $\begin{array}{l}\text { Mea } \\
\mathrm{n} \pm\end{array}$ \\
\hline Lower & $<33(<$ & 33 & 35.1 & 38.9 \\
efficac & $50 \%)$ & & & $4 \pm$ \\
$\mathrm{y}$ & & & & 1.55 \\
$\begin{array}{l}\text { Higher } \\
\text { efficac }\end{array}$ & $\begin{array}{l}\mathbf{\mathbf { 0 } 3 3} \\
(\mathbf{0 5 0 \%}\end{array}$ & 61 & 64.9 & \\
$\mathrm{y}$ & ) & & & \\
\hline
\end{tabular}

Most of the respondents (64.9\%) had higher efficacy in self care. The mean self care score was $38.94 \pm 1.55$. (Table 9)

Table 10: Comparison of mean difference of Knowledge with Variables: $\mathbf{N}=94$

\begin{tabular}{|c|c|c|c|c|c|c|c|}
\hline Variables & & Frequency & $\begin{array}{c}\text { Possible } \\
\text { score }\end{array}$ & Mean & $\begin{array}{c}\text { Std. } \\
\text { Deviation }\end{array}$ & $t$ value & $\mathrm{p}$ value \\
\hline & Illiterate & & & & & & \\
\hline \multirow{2}{*}{ Education level } & & 16 & & 3.31 & 2.24 & -1.01 & 0.31 \\
\hline & Literate & 78 & & 3.87 & 1.96 & & \\
\hline \multirow[t]{2}{*}{$\begin{array}{l}\text { Pre operative } \\
\text { teaching }\end{array}$} & No & 30 & & 4.40 & 1.73 & 2.09 & 003 \\
\hline & Yes & 64 & & 3.48 & 2.07 & & \\
\hline \multirow[t]{2}{*}{$\begin{array}{l}\text { Training on stoma } \\
\text { care }\end{array}$} & No & 66 & $1-6$ & 3.25 & 2.07 & -4.165 & 000 \\
\hline & Yes & 28 & & 5.00 & 1.15 & & \\
\hline \multirow[t]{2}{*}{$\begin{array}{l}\text { Duration of living } \\
\text { with stoma }\end{array}$} & a 12 months & 44 & & 3.18 & 2.08 & -2.78 & م \\
\hline & $>12$ months & 50 & & 4.30 & 1.80 & & \\
\hline
\end{tabular}

The mean knowledge score of illiterate was 3.31 and that of literate was 3.87 , which is slightly different but it is statistically insignificant since $\mathrm{p}$ value is 0.314 .

The mean knowledge score of ostomates receiving and not receiving pre-operative teaching were 4.40 and 3.48 respectively. The difference is statistically significant since $\mathrm{p}$ value is 0.03 .

The mean knowledge score of ostomates receiving training was 5.00 and that of not receiving training was 3.25 , which is significantly significant as p value is 0.00 . 
The mean knowledge score of ostomates living with stoma for $\mathbf{0} 12$ months was 3.18 and that of living with stoma for $>12$ months

Table 11: Comparison of mean Self Care Efficacy with Variables N=94

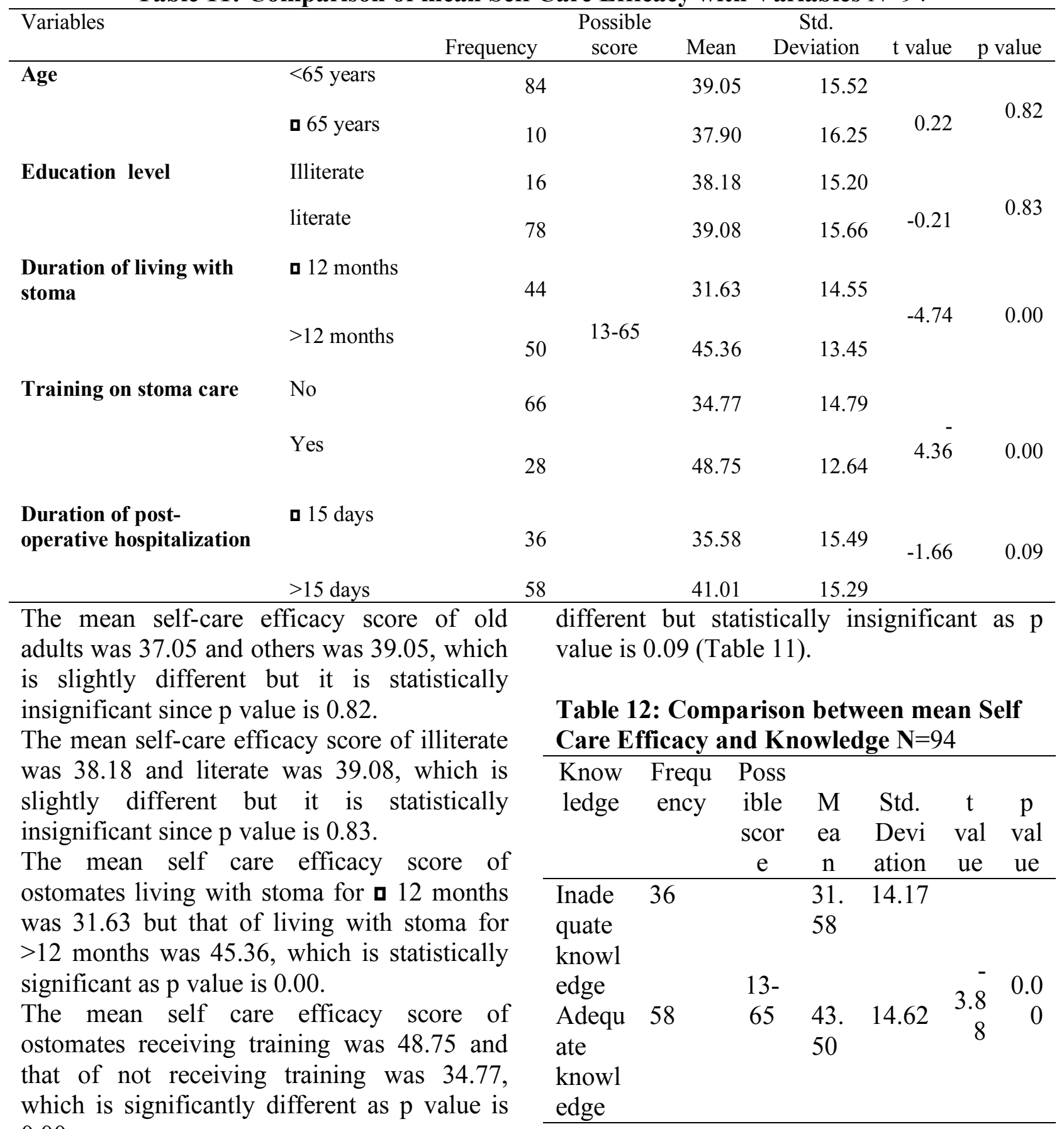
0.00 .

The mean self care efficacy score of ostomates having duration of post operative hospitalization $\mathbf{1} 15$ days was 35.58 and that of $>15$ days was 41.01, which is slightly was 4.30, which is significantly different as $\mathrm{p}$ value is 0.00 (Table 10). 
43.50, which is statistically significant as $p$ value is 0.00 (Table 12).

\section{Discussion}

The socio-demographic findings of the study revealed that most of the respondents $(61.7 \%)$ were male. The findings were similar to the study done among patients of colorectal cancer resulting in an ostomy, which was seen more in males and a urostomy for bladder cancer was predominately associated with males.(1) The mean age of the respondents was 48.9 years (range 21-80 years), which is similar to the study in Iran in which mean age was 57.49 years (SD 12.28 years) [15].

In this study majority (70.2\%) had colostomy. Most of the respondents $(61.7 \%)$ had postoperative hospitalization of $>15$ days. Regarding duration of living with stoma, more than half ostomates $(53.2 \%)$ were living with stoma for $>12$ months. Majority of ostomates $(70.2 \%)$ visiting stoma clinic had not received training on stoma care. Preoperative teaching on stoma was provided during stoma site marking and at OPD before consent by concerned doctors. Among the respondents majority $68.1 \%$ had received preoperative teaching.

An Interventional study was done among Permanent Colostomy in china to assess knowledge about colostomy care, colostomy products, prevention and treatment of complications, types and storage of colostomy bags, and colostomy irrigation. Higher scores represent higher level of knowledge. The result showed pre-course mean [SD] was knowledge 51.89 [11.45]. Similarly self care efficacy was 71.56 [5.93] [7]. In this study the overall knowledge of respondents on normal stoma and stoma related complication is $61.7 \%$. Mean [SD]: 3.77 [2.01]. Higher self care efficacy was $64.9 \%$. Mean [SD] self care efficacy was 38.94 [1.55].
Similar study was done among stoma patients in Taiwan using a randomised experimental design. Stoma patients were randomly assigned to multimedia learning education program and a conventional education service program with a follow-up of one week. Knowledge of self care scale consisting of 22 items related to: anatomy of stoma, types of pouching systems and types of accessories was used and was rated on a dichotomized scale (1, right; 0 , wrong). The pretest mean [SD] scores in Knowledge of Self Care was 7.30 [3.97] [16].

In a descriptive study done to examine adjustment and its relationship with stoma care self-efficacy, among patients using 13 point Self-efficacy Scale in UK. Higher scores correspond to higher levels of confidence. Stoma-care self-efficacy accounted for $57.5 \%$ [12]. The finding is similar to this study in which higher self care efficacy of ostomates comprises of $64.9 \%$.

In this study there is no significant difference in mean self care efficacy between old adult and others, illiterate and literate. This is in contrast to the study done on self efficacy and quality of life among stoma patients in Hong Kong in which factors associated with lower self efficacy included increasing age, lower education level [17].

In a cross-sectional study done to assess Selfefficacy and the related factors in ostomates among patients with ostomy in Iran using personal information form and Stoma SelfEfficacy Scale (Stoma SE Scale), half of the participants gained at least half of the overall self-efficacy scores. The mean score of social self-efficacy was lower than the mean score of stoma care self-efficacy. Self-efficacy was associated with marital status, stoma status and stoma duration $(\mathrm{P}<0.05)$ but the relationship between self-efficacy and age, gender, educational level, type of stoma and 
reason of stoma was not statistically significant [18]. These findings are similar to this study as there was significant difference in stoma duration but not with age and education level.

In a study done to study peristomal skin disorder in patient with permanent stomas peristomal skin irritation accounts for $72.3 \%$ of physical problem due to stoma [19]. This is similar to this study where physical problem due to stoma accounts for $89.4 \%$.

\section{Conclusion}

This study finding shows majority of ostomates suffer from physical problem. Hence it is recommended to concerned authority to identify reason behind it and conduct package training program to reduce physical problem.

\section{REFERENCES}

1. Beitz J. Gastrointestinal etiologies leading to a fecal diversion. Disease of colon and rectum.2004:136-159.

2. Fulham J. A guide to caring for patients with a newly formed stoma in the acute hospital setting. Gastrointestinal nursing. 2008;6(8).

3. Pradhananga K, Baral, M., Shrestha, BM. Multi-institution hospital based cancer incidence data for Nepal- An initial report. Asia Pacific Journal of Cancer Prevention. 2009;10:259-62.

4. ВРКМСН. Annual Report-2010. 2010:33, 76.

5. Bajracharya S. The Road of Stoma Care in Nepal. World Council of Enterostomal Therapist 2010:8-10

6. Izard S. Case study-stoma care in Nepal. The Outlet- New Zealand stomal therapy Nurses. 2010:6.

7. Cheng F, Xu, Q., Dai, XD., Yang, LI. Evaluation of the Expert Patient Program in a Chinese Population With Permanent Colostomy. Cancer NursingTM.2012;35:1, nE27.

8. Silva M, Ratnayake, G., Deen, KI. Quality of life of stoma patients: temporary ileostomy versus colostomy. World journal of surgery. 2003(27):421-424.

9. Ross L, Abild-Nielsen, AG., Thomsen, BL., Karlsen, RV., Boesen, EH., Johansen, C. Quality of life of Danish colorectal cancer patients with and without a stoma. Supportive Care in Cancer. 2007;15(5):505-513.

10. Gooszen A, Geelkerken, RH., Hermans, J.,lagaay,MB., Gooszen, HG. Quality of life with a temporary stoma: Illeostomy Vs colostomy. Disease of Colon and Rectum. 2000:650-655.

11. Strode D. How do people adjust to living with stoma? A nurses search for literature. journal of clinical Nursing.2009.(1):76.

12. Simmons K, Smith, J., Bobb, K., Liles, L. Adjustment to colostomy: stoma acceptance, stoma care self-efficacy, and interpersonal relationships The AuthorsJournal compilation, JAN Original Research. 2007:627-635.

13. Colwell JC, Gray, M. Does preoperative teaching and stoma site marking affect surgical outcomes in patients undergoing ostomy surgery? Journal of Wound, Ostomy and Continence Nursing. 2007;34(5):492-496.

14. Diament H. Clinical nurse specialists Stoma care. Journal of Wound , Ostomy Continennce. 2009:525.

15. Mahjoubi.B. MA, Mirazaei. L., Bijari. A., . Evaluation of end colostomy complications and the risk factors influencing them in Iranian patients. Colorectal Disease. 2005;7(6):582-587.

16. Lo S, Wang, YT., Wu, LY., Hsu, MY., Chang,SC., Hayter, M. A cost-effectiveness analysis of a multimedia learning education program for stoma patients. Journal of clinical nursing. 2009(19):1844-54.

17 Wu HK-M, Chau, J. P.- C., Twinn, S. Selfefficacy and quality of life among stoma patients in Hong Kong. Cancer Nursing. 2007; 30(3):18693.

18. Rafii. F. NL, Parvizy. S., Haghani. H. Selfefficacy and the Related Factors in Ostomates. Iran Journal of Nursing. 2012;24(73):8-18.

19. Herlufsen P, Olsen, AG., Carlsen, B., Nybaek, H., Karlsmark, T., Laursen, TN., et al. Study of peristomal skin disorders in patients with permanent stomas. British Journal of Nursing. 2006;15(16):854-62.

Correspondence Address: Radha Acharya Pandey, Assistant Professor, Nursing, Kathmandu University School of Medical Sciences, Dhulikhel Hospital, Dhulikhel, Kavre 